\title{
Metastasizing oral melanoma in a cow
}

\author{
Melanoma oral metastático em uma vaca
}

\section{Marilene de Farias Brito ${ }^{\mathrm{I}}$ Ticiana Nascimento França ${ }^{\mathrm{II}}$ Flávia Figueiraujo Jabour ${ }^{\mathrm{II}}$ Josilene Nascimento Seixas ${ }^{\text {III }}$ Gisele Braziliano Andrade ${ }^{\text {IV }}$ Laura Iglesias Oliveira $^{\text {IV }}$ Paulo Vargas Peixotov}

\begin{abstract}
A malignant dendritic melanoma of the oral cavity ABSTRACT with metastases widely spread in a cow is described. The clinicopathological manifestations, developed during a twoyear period, was characterized by the difficulty in mastication and swallowing, progressive weight loss, weakness and profuse sialorrhea. At the necropsy, an ulcerated black mass was found at the left jaw projecting into the oral cavity. The tumor reached the chin, inferior lip and tongue. Metastases were detected within the tongue, parotid gland, lymph nodes, trachea, thyroid, pleura, lungs, heart, peritoneum, omentum, and serosal membranes of the forestomach and abomasum, liver, and intima of some hepatic vessels, mammary gland, and muscles and fasciae of the left hind leg. No reference to metastasizing oral dendritic melanoma in the oral cavity of the cattle has been mentioned in the literature.
\end{abstract}

Key words: oral dendritic melanoma, cattle, pathology, neoplasm.

\section{RESUMO}

Neste trabalho, descreve-se um caso de melanoma dendrítico maligno da cavidade oral em uma vaca, com metástases amplamente disseminadas. A evolução clínica foi de dois anos, e o quadro clínico-patológico caracterizou-se por dificuldade na mastigação e deglutição, perda de peso progressiva, fraqueza e sialorréia profusa. À necropsia, uma massa enegrecida e ulcerada foi encontrada na mandíbula esquerda e projetava-se para a cavidade oral. O tumor envolvia principalmente a porção cranial do ramo horizontal esquerdo da mandíbula e alcançou o mento, o lábio inferior, a gengiva e a língua. Metástases foram detectadas na língua, na glândula parótida, nos linfonodos, na traquéia, na tireóide, na pleura, nos pulmões, no coração, no peritônio, no omento e na serosa dos pré-estômagos e do abomaso, do fígado e da íntima de alguns vasos hepáticos, da glândula mamária e das fáscias $e$ dos músculos do membro posterior esquerdo. Histologicamente o tumor primário e as metástases eram do tipo dendrítico. Não encontramos referências a melanomas primários de mandíbula com metástases em bovinos.

Palavras-chave: melanoma dendrítico oral, bovino, patologia, neoplasia.

Melanomas originate from neuroectodermal melanoblasts, which migrate at the beginning of the development period into the epidermal-dermal junction of the skin, follicles, and dermis. They are also found in ocular structures, meninges, adrenal glands, endocardium, and intima of blood vessels (PULLEY \& STANNARD, 1990). These neoplasms are common in dogs and in gray or white horses; the incidence is occasional in the Duroc and Sinclair miniature swine by genetic predisposition, and they are less frequent in cats and sheep. Although the congenital form is well

IDepartamento de Epidemiologia e Saúde Pública, Instituto de Veterinária, Universidade Federal Rural do Rio de Janeiro (UFRRJ), BR 465, km 7, 23890-000, Seropédica, RJ, Brasil. E-Mail: marilene@ufrrj.br. Autor para correspondência.

"Universidade Federal do Rio de Janeiro (UFRJ)e Universidade Estácio de Sá, Rio de Janeiro, RJ, Brasil.

IIIPrograma de Pós-graduação em Medicina Veterinária, UFRRJ, Seropédica, RJ, Brasil.

${ }^{\mathrm{IV}}$ Departamento de Epidemiologia e Saúde Pública, Instituto de Veterinária, UFRRJ, Seropédica, RJ, Brasil.

vDepartamento de Nutrição Animal e Pastagem, Instituto de Zootecnia, UFRRJ, Seropédica, RJ, Brasil. 
known, melanomas are also common in Suffolk sheep and Angora goats of different ages (SMITH et al., 2002). Melanocytic tumors are rare in cattle (MILLER et al., 1995; SMITH et al., 2002; GODOY et al., 2003) and usually account for $5 \%$ to $6 \%$ of all tumors in this species (MILLER et al., 1995; SMITH et al., 2002) especially in the Aberdeen Angus breeds (SCOTT, 1988; YERUHAN et al., 1999). Some melanocytic tumors are congenital(MILLER et al., 1995; SIVADAS et al., 1971; YERUHAN et al., 1999) or occur in cattle younger than two years old (MILLER et al., 1995; SIVADAS et al., 1971; WISEMAN et al., 1977) especially those of red, gray or black skin (MILLER et al., 1995; SLOMINSKI et al., 2001). The tumors may also be found on the jaw (WISEMAN et al., 1977; HEAD et al., 2002) maxilla (MISDORP, 2002), trunk, limbs (MILLER et al., 1995) and less frequently in the interdigital regions (GODOY et al., 2003) and in the eyes (MISDORP, 2002). Melanomas in the vertical branch of the jaw have been described in a 14-month-old Charolais and a 9-monthold Ayrshire, and were already present at birth in the latter (WISEMAN et al., 1977). Although the origin and pathogenesis of cutaneous melanomas are still unknown in animals, there is some evidence that the majority arise from epidermal, dermal, ocular and oral epithelia (CONROY, 1967). Malignant transformation from benign processes is rare in animals except gray horses (CONROY, 1967; GOLDSCHMIDT, 1985). It is claimed that the majority of melanomas of human and also of Angora goat is caused by secondary mutations due to ultra-violet radiation of the types UVA (320400nm) and UVB(290-320nm)(SLOMINSKI et al., 2001). According to the predominant cell type, melanomas are classified as epithelioid, spindle cell melanomas, mixed (GOLDSCHMIDT et al., 1998; WEISS \& FRESE, 1974; YAGER \& SCOTT, 1993; GROSS et al., 2005) and whorled or dendritic melanomas (WEISS \& FRESE, 1974; SMITH et al., 2002; ZEMBOWICZ \& MIHM, 2004; GROSS et al., 2005).

The melanocytic tumor reported here was found in a Friesian cross-bred cow of 3 years and 6 months of age in the State of Rio de Janeiro, Brazil. The history and clinical data were obtained during a visit to the farm in June 2004. A post-mortem examination was performed immediately after euthanasia; samples from different organs were collected, fixed in $10 \%$ formalin solution and routinely processed for histopathological evolution. Some slides were bleached with $30 \%$ hydrogen peroxide in order to observe details of cell characteristics.

According to information from the owner, a large and deep myiasis developed two years ago in the mandibular region of the cow, with posterior progressive tissue growth in the oral cavity causing deformity of the face. The animal developed progressive weight loss, experienced difficulties in mastication and swallowing, cachexia, weakness, dehydration, debility, and profuse sialorrhea. There was loss of ruminal fluid from the mouth and impaired rumination, and the hair coat was dry and rough.

At the necropsy, a multiple nodular and ulcerated mass of $20 \mathrm{~cm}$ in diameter was observed on the external cranial portion of the left horizontal branch of the jawbone, extending into the oral cavity. The outer surface was necrotic with loosening of the skin and extensive myiasis. In the oral cavity, the infiltrative mass of irregular outline was subdivided into two large lobes that involved the lower lip, tongue, left (in major extension) and right horizontal branch of the jawbone (ventral face). At the left horizontal branch of the jawbone, the tumor caused loosening of the teeth, with displacement of the premolar teeth behind the medial incisors (Figure 1A). The tumor was thoroughly black, of firm consistency with necrotic areas. After dissection, the tumor weighed $560 \mathrm{~g}$. The ventral surface of the tongue presented black strips corresponding to lymphatic invasion. The left parotid gland was moderately enlarged and darkened, and its parenchyma almost completely invaded by neoplastic growth. Local lymphatic and blood vessels were dilated and darkened, and were connected to the largest jawbone mass, parotid lymph nodes and parotid gland. The lymph and hemolymph nodes, mainly in the cervical region close to the thorax opening, were enlarged and pigmented. A black mass occupied a great part of the thyroid parenchyma (Figure 1B). Multiple foci and/or black nodules were observed at the pleura (Figure 1C). Other metastases were randomly distributed throughout the pulmonary parenchyma, endocardium, epicardium and myocardium. Black spots were noted on the peritoneum, omentum, and the serous membrane of the gastric compartment, as well as in the mesenteric and aortic-lumbar lymph nodes. In the liver, there were numerous firm and black metastatic foci under the capsule and in the parenchyma, from point-like to $6 \mathrm{~cm}$ in diameter (Figure 1D). The intima of some hepatic veins was black because of the adhered embolic tumor. Within the mammary gland, there was a metastatic nodule measuring $0.5 \mathrm{~cm}$ in diameter, and metastatic tumorous growth at the muscles and fasciae of the left posterior limb had small black spots.

Histologically the tumor was composed of heavily pigmented spindle-shaped cells with a highly angular shape or stellate, sometimes with long cytoplasmic processes, arranged in sheets in a bandlike pattern (Figure 1E e 1F), and sometimes whorled. 


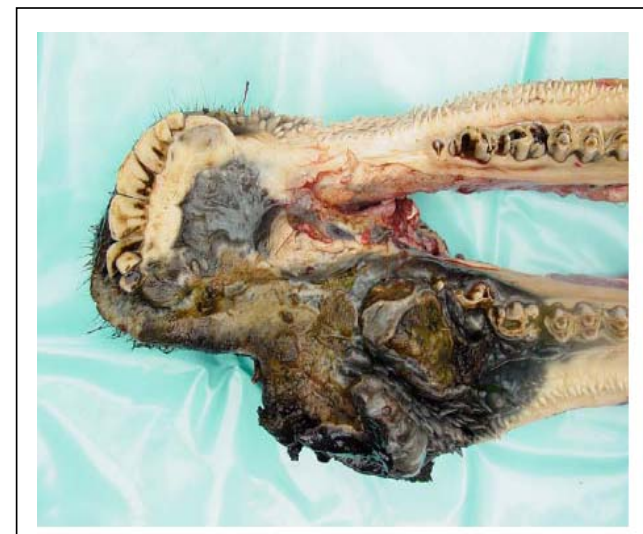

A

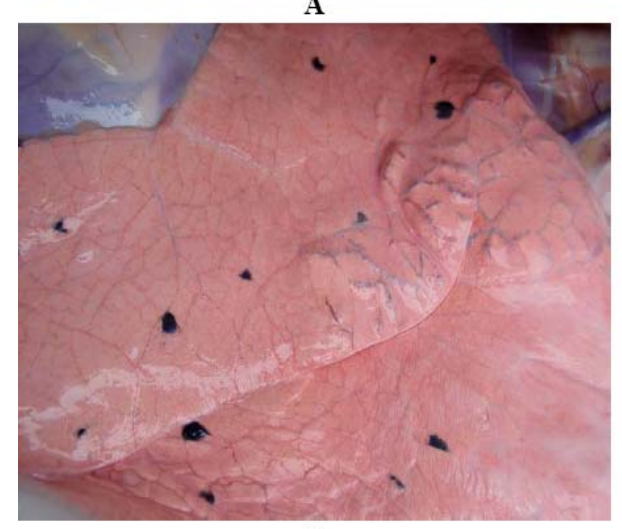

C

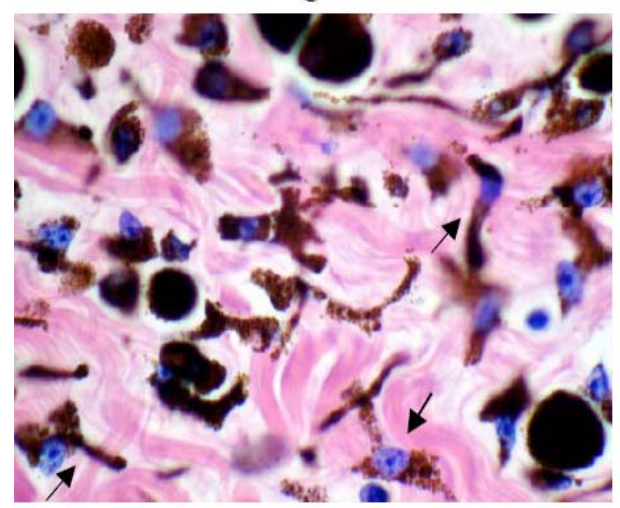

E

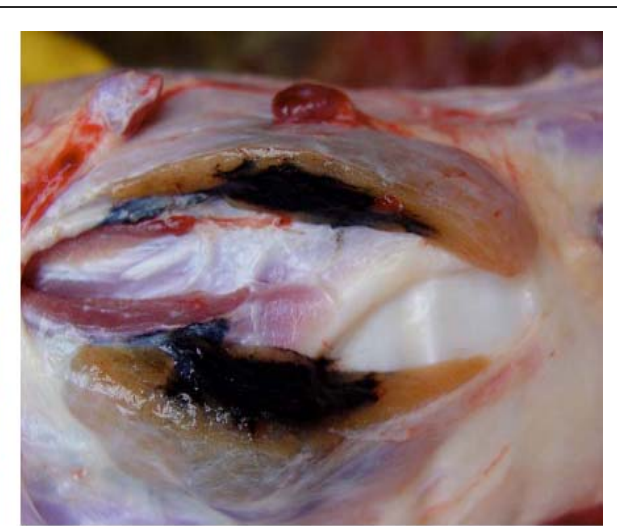

B

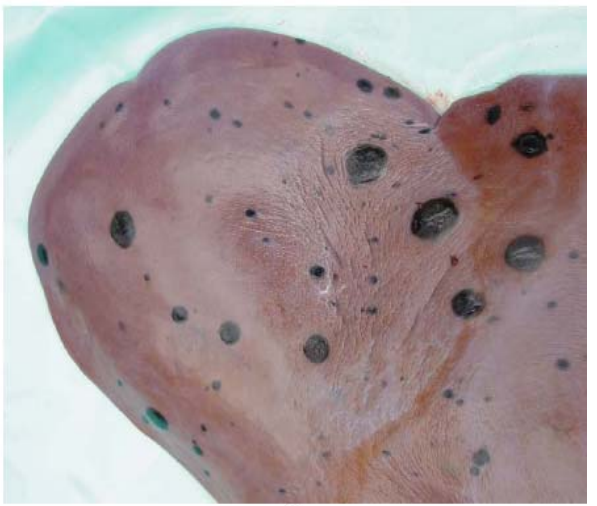

D

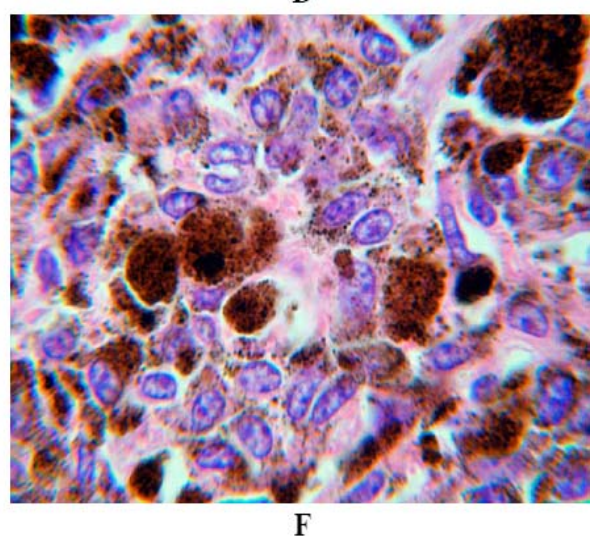

Figure 1 - Oral dendritic melanoma in a cow with widespread metastases. A. Infiltrative mass in left horizontal branch of the jawbone. B. Thyroid metastasis. C. Pulmonary metastases. D. Hepatic metastases. E. Dendritic-like cells (arrows) and melanin filled melanophages in gum. HE. x 400. F. Proliferation of neoplastic melanocytes and melanin filled melanophages in gum. HE. x 1000.

Most cells had small, round to oval nuclei containing 1-2 round nucleoli with delicate chromatin and abundant granular black pigment in the cytoplasm, in which the pigment darkened the cellular details. There were also strikingly large, polyhedral or round, welldelimited pigment-containing melanophages, which were more abundant than dendritic cells and were distributed throughout the neoplasm. Stromal collagen was minimal, and mitoses were absent or sparsely visible (less than one mitotic figure/ten 40x fields). Junctional activity was not observed. There was a low nucleus to cytoplasm ratio. Anisocytosis, anisokaryosis, and atypia were discrete. Neoplastic cells infiltrated the tongue, salivary glands, gums and lips. Bone invasion and jawbone osteolysis were observed.

Ciência Rural, v.39, n.4, jul, 2009. 
Metastases in other organs had the same microscopic characteristics of the primary tumor.

The diagnosis of malignant melanoma was based on the typical macroscopic and microscopic aspects of the neoplasm. The emergence of myiasis two years before at the same place of the primary tumor indicated that the neoplasm probably developed when the animal was one year old (juvenile melanomas), in accordance with many reports of melanomas in cattle (SIVADAS et al., 1971; WISEMAN et al., 1977). Despite the reports in sheep and goats, metastases of cutaneous melanomas in cattle are rare (SCOTT, 1988; MILLER et al., 1995). Melanomas are found in the ramus of the mandible of ox, and in sheep at the abattoir (HEAD et al., 2002). Malignant melanomas are also occasionally observed in the horizontal branch of the jawbone in cattle and sheep in the slaughterhouse, and although these tumors are large enough to cause lower jawbone fracture, metastases have not been described.

Twenty-five melanomas were described in calves (14 congenital and 11 juvenile). One of them invaded and destroyed the maxillary region and metastasized to many organs, however, the author believes the primary tumor was in the eye (MISDORP, 2002).

The behavior of the oral melanoma in the present case was comparable to oral cavity melanomas of dogs. In this species, distinguishing whether the origin is from haired skin or mucous membrane of the lip or conjunctiva is important because mucous membrane tumors have a more aggressive behavior not necessarily predicted by their histological appearance. In dogs, mitotic index is the best prognostic indicator, with more than two mitoses/ten 40x fields associated with a high probability (73\%) of tumorinduced death within two years (YAGER \& WILCOCK, 1994). On the other hand, a satisfactory predictive model that employed mitotic index could not be constructed, but one using nuclear atypia gave an overall correct classification in $93.3 \%$ of the cases. (SPANGLER \& KASS, 2006).

The neoplasm observed here is identical to the dendritic melanomas described by WEISS \& FRESE (1974) although there is no mention of this tumoral histological variant in the new classification of The WHO (GOLDSCHMIDT et al., 1998). On the other hand, ZEMBOWICZ \& MIHM (2004) considers that most of the histological variants recently introduced in the medical literature such as amelanotic/hypomelanotic blue naevus, amelanotic cellular blue naevus, epithelioid blue nevus, compound blue naevus, atypical blue naevus, pilar neurocristic hamartoma, blue naevus-like metastatic melanoma, pigmented epithelioid melanocytoma and cutaneous neurocristic harmatoma/ malignant neurocristic tumors could be classified as traditional categories of dendritic melanocytic proliferations.

Some similar morphologic characteristics between jawbone tumors in cattle and the infant neuroectodermal melanocytic progonoma are mentioned (WISEMAN et al., 1977). In humans, these tumors can sometimes generate metastases (NAVAS PALACIOS, 1980), although in cattle they are benign (WISEMAN et al., 1977). Another similar tumor of this type was reported in a 7-month-old Aberdeen Angus calf and diagnosed as congenital fibrotic melanoma (LONG et al., 1981).

Melanocytic dendritic neoplasm is rare, generally benign and apparently has been described only on the skin (WEISS \& FRESE, 1974; SMITH et al., 2002). Evident anaplastic characteristics as seen in malignant epithelioid and spindle melanoma are generally absent in this histologic variant (WEISS \& FRESE, 1974). Usually, metastasizing malignant melanomas show marked pleomorphism and a high mitotic index (SMITH et al., 2002) characteristics that were not observed in this case. Anaplasia with cell pleomorphism and varying degrees of mitotic activity are characteristic for all malignant variants except the dendritic and whorled types (WEISS \& FRESE, 1974).

References to dendritic malignant melanomas in cattle have not been found. Regardless of the origin of the tumor, this case might represent the first description of an oral melanoma with metastases in cattle.

\section{REFERENCES}

CONROY, J.D. Melanocytic tumors of domestic animals. Archive Dermatology, v.96, p.372-380, 1967.

GODOY, G.S. et al. Neoplasias melanocíticas em bovinos da raça Nelore: relato de dois casos. In: ENCONTRO NACIONAL DE PATOLOGIA VETERINÁRIA, 11., 2003, FMVZ-UNESP. Anais... Botucatu, SP: UNESP, 2003. p.276.

GOLDSCHMIDT, M.H. Benign and malignant melanocytic neoplasms of domestic animals. American Journal Dermatopathology, v.7, p.203-212, 1985.

GOLDSCHMIDT, M.H. et al. Melanocytic tumors and tumorlike lesions. In: GOLDSCHMIDT M.H. et al. Histological classification of epithelial and melanocytic tumors of the skin of domestic animals. Washington: Armed Forces Institute of Pathology, 1998. p.38-40.

GROSS, T.L. et al. Melanocytic tumors. In: GROSS, T.L. et al. Skin diseases of the dog and cat. Clinical and histopathologic diagnosis. 2.ed. Iowa: Blackwell, 2005. p.813-836. 
HEAD, K.W. et al. Tumors of the alimentary tract. In: MEUTEN, D.J. Tumors in domestic animals. 4.ed. Iowa: Blackwell, 2002. p.430-431.

LONG, G.G. et al. Fibrotic melanoma in a calf. Veterinary Pathology, v.18, p.402-404, 1981.

MILLER, M.A. et al. Cutaneous melanocytomas in 10 young cattle. Veterinary Pathology, v.32, p.479-484, 1995.

MISDORP, W. Tumours in calves: comparative aspects. Journal Comparative Pathology, v.127, p.96-105, 2002. Disponível em: http:/ /www.sciencedirect.com/science?_ob=ArticleURL\&_udi=B6WHW46THBFS-D\&_user $=687358 \&$ _rdoc $=1 \&$ \&mt $=$ \&_orig $=$ search \&_s ort $=\mathrm{d} \&$ view $=\mathrm{c} \&$ acct $=\mathrm{C} 000037899 \&$ _version $=1 \&$ \& urlVersio $\mathrm{n}=0$ \&_userid=687358\&md5=877b07d709c13fc73db94e3021f23058. Doi: $10.1053 /$ jcpa.2002.0563.

NAVAS PALACIOS, J.J. Malignant melanotic neuroectodermal tumor: light and electron microscopic study. Cancer, v.46, p.52936, 1980. Disponível em: http://www3.interscience.wiley.com/ journal $/ 112679260 /$ abstract?CRETRY $=1 \&$ SRETRY $=0$. Doi: $10.1002 / 1097-0142(19800801) 46: 3<529$ : : A D CNCR2820460318>3.0.CO;2-4.

PULLEY, L.T.; STANNARD, A. Tumors of the skin and soft tissues. In: MOULTON, J.E. Tumors in domestic animals. 3.ed. London: Berkeley, 1990. p.75-82.

SCOTT, D.W. Neoplastic diseases. In: SCOTT, D.W. Large animal dermatology. Philadelphia: Saunders, 1988. p.448452 .

SIVADAS, C.G. et al. Congenital melanoma in a calf. A review and case report. British Veteterinary Journal, v.127, p.289293, 1971.
SLOMINSKI, A. et al. Malignant melanoma: an update. Archive Pathology Laboratoy Medicine, v.125, p.1295-1306, 2001.

SMITH, S.H. et al. A comparative review of melanocytic neoplasms. Veterinary Pathology, v.39, p.651-678, 2002.

SPANGLER, W.L.; KASS, P.H. The histologic and epidemiologic bases for prognostic cosiderations in canine melanocytic neoplasia. Veterinary Pathology, v.43, p.136149, 2006

WEISS, E.; FRESE, K. International histological classification of tumours of domestic animals. Genève: World Health Organization, 1974. 142p. (Bulletin of the World Health Organization).

WISEMAN, A. et al. Melanocitic neuro-ectodermal tumour of infancy (melanocytic progonoma) in two calves. Veterinary Record, v.101, p.264-266, 1977.

YAGER, J.A.; SCOTT, D.W. Neoplastic diseases of skin and mammary gland. In: JUBB, K.V.F. et al. Pathology of animals domestic. 4.ed. San Diego: Academic, 1993. V.1, p.719-721.

YAGER, J.A.; WILCOCK, B.P. Other cutaneous mesenchymal tumours. In: YAGER, J.A.; WILCOCK, B.P. Color atlas and text of surgical pathology of the dog and cat. Dermatopathology and skin tumors. London: Wolfe, 1994. p.304-307.

YERUHAN, I. et al. Congenital skin neoplasia in catle. Veterinary Dermatology, v.10, p.149-156, 1999.

ZEMBOWICZ, A.; MIHM, M.C. Dermal dendritic melanocytic proliferations: an update. Histopathology, v.45, p.433-451, 2004. Disponível em: http://www3.interscience.wiley.com/journal/ 118779057/abstract. Doi: 10.1111/j.1365-2559.2004.01975.x. 